\title{
O fenômeno chamado Aparecida
}

Roseane do Socorro Gomes Barbosa ${ }^{1}$

Ao lançarmos um olhar sobre a história de Aparecida na perspectiva da Ciências da Religião, nos encontramos frente a um fenômeno fácil de ser narrado, porém cheio de nuanças para ser bem compreendido não somente como uma devoção religiosa popular, mas como elemento constitutivo da identidade do povo brasileiro.

Entre os muitos aspectos que poderiam ser analisados na história que chegou até nós, destacamos três os quais demonstram com maior intensidade como uma pequenina imagem de barro, cuja cabeça estava separada do corpo, e encontrada no fundo de um rio, tornou-se a "Rainha do Brasil". O primeiro aspecto encontra-se na importância da imagem de Aparecida para identidade em construção do povo brasileiro. Um segundo é a questão da inculturação da devoção a Nossa Senhora da Conceição que era popular no Reino de Portugal e foi transplantada para o Brasil com novas características. E por fim os aspectos bíblicos e até míticos que permeiam a história de Aparecida.

Em 1717, quando o corpo e a cabeça da imagem de Nossa Senhora da Conceição foram pescados no rio Paraíba do Sul (SP), o Brasil era uma colônia de Portugal, e o povo que aqui vivia não tinha uma identidade própria, assim como compreendemos hoje o que é ser povo brasileiro. Todos os costumes e tradições dos povos nativos, que aqui viviam, foram suplantados pela cultura e costumes dos colonizadores que contavam com o apoio e a legitimação da Igreja católica, a qual buscava cristianizar e catequizar a nativos e os escravizados que foram trazidos ou traficados para o Brasil.

Quase um século após o achado da imagem, em 1815 o Brasil foi elevado à condição de Reino Unido Portugal, Brasil e Algarves. E, em 1822, ascendeu ao status de Império com a proclamação da independência do Brasil, em relação a Portugal. Paralelamente a esses acontecimentos que mudaram a história do Brasil, a devoção a Nossa Senhora Aparecida crescia paulatinamente, sem fazer muito barulho, mas, vertiginosamente, no que nós chamaríamos hoje de propaganda boca a boca.

Um dado importante para essa história é o fato de que em 1846, a devoção a Nossa Senhora da Conceição tornara-se oficial em todo o Reino de Portugal, ou seja, estavam incluídas também todas as colônias do reino. Sendo assim Nossa Senhora da Conceição não era nenhuma "estranha" no Brasil, o que poderia ter dado mais forças à imagem achada um século atrás. Contudo tal devoção não era uma simples reprodução daquela que se tinha na capital do Império, pois aqui adquiriu um novo adjetivo e uma nova cor, ou seja, ela é Aparecida e é negra.

\footnotetext{
${ }^{1}$ Mestra em Ciências da Religião pela PUC-SP e Bacharel em Teologia pela PUC-RIO. É membro da Congregação das Filhas de São Paulo (Irmãs Paulinas), e missionária nos Estados Unidos.
} 
Essa história teve o seu começo não por meio de uma revelação, ou tampouco numa visão de algum vidente, mas numa pesca que despontou de frustrante a milagrosa. Foi assim que nasceu a devoção àquela pequena e negra imagem, que por ter sido encontrada chamouse de Nossa Senhora da Conceição Aparecida e que em 1904 recebeu de presente uma coroa das mãos de Princesa Isabel, e em 1930 tornou-se a "Rainha" e padroeira do Brasil pelo decreto do Papa Pio XI. Um título tão imponente dado a uma imagem tão pequenina, mas que suscitou uma fé gigantesca do tamanho do Brasil e do povo brasileiro.

A história dessa devoção é marcada por vários aspectos bíblicos e míticos que se traduzem numa verdadeira catequese. Aparecida é feita da terra, assim como a humanidade foi modelada pelo Criador no relato de Gênesis. Ela é tirada das águas semelhante a Moisés que se tornou o grande libertador do povo hebreu segundo a narrativa do Pentateuco. O primeiro milagre é uma pesca milagrosa idêntica a que é narrada nos evangelhos de Lucas e João. Há também a cura de uma menina cega de nascença semelhante ao que é narrado pelo evangelista João. E o que une Aparecida aos relatos bíblicos? A fé que é o elemento essencial para que haja milagres.

Enfim, ao destacarmos essas três nuanças da história de Aparecida torna-se compreensível, para além da religiosidade popular, a identificação do povo brasileiro com aquela imagem. A analogia é quase plasmática uma pequenina imagem, descabeçada, preta e no fundo de um rio, semelhante ao povo brasileiro, também pequeno, sem rosto e nos confins do Império. Esses e tantos outros aspectos nos fazem compreender porque o "fenômeno" Aparecida contribuiu para a formação da cultura e da fé no Brasil.

\section{Para refletir:}

Que relação podemos tecer entre a imagem de Aparecida e a identidade do povo brasileiro? Porque a devoção a Aparecida cresceu velozmente entre os mais simples, e não se restringiu a esses?

\section{Bibliografia}

ALVAREZ, Rodrigo. Aparecida - a biografia da santa que perdeu a cabeça, ficou negra, foi roubada, cobiçada pelos políticos e conquistou o Brasil. São Paulo: Editora Globo, 2014. BOFF, Lina. Aparecida: $\mathbf{3 0 0}$ anos de romaria em prece. São Paulo: Paulinas, 2017. 